\title{
Pendidikan Akidah Akhlak \\ dengan Metode Brain Based Learning
}

\author{
Ardi Sahrul Arizal \\ Universitas Ahmad Dahlan (UAD) Yogyakarta \\ ardiarizal@gmail.com \\ Alda Rizka Fatkhia \\ Universitas Ahmad Dahlan (UAD) Yogyakarta \\ aldarizkafatkhia@gmail.com \\ Cut Zahiya Listy Humairah \\ Universitas Ahmad Dahlan (UAD) Yogyakarta \\ cutzahiyalisty@gmail.com \\ Arif Sugianto \\ Universitas Ahmad Dahlan (UAD) Yogyakarta \\ arifsugianto@gmail.com \\ Muhammad Aziz Umar \\ Universitas Ahmad Dahlan (UAD) Yogyakarta \\ muhammadazizumar@gmail.com \\ Isma Yulia \\ Universitas Ahmad Dahlan (UAD) Yogyakarta \\ isma@gmail.com
}

\begin{abstract}
This paper discusses the development of human morality and akidah using brain based learning. The author are aaindentifies the existence of static learning in moral and akidah education.To create more fun and modern moral learning, a brain based learning method was created.In it contains a strategy about moral akidah learning that uses brain based learning methods that are also combined with learners who are active and effective and in line with it, in order to form human beings who have noble character and strong convictions to disperse Allah, then it is more concerned with planting good person. This learning refers to empowering the potential of the brain so that humans can think critically and cooperatively in supporting the life of their faith and character in accordance with the guidelines of the Qur'an and hadith. In moral akidah education where the times have reached the distribution era, the
\end{abstract}


application of brain based learning methods is very appropriate to be used as a response to the destructive era.

Keywords: akidah akhlak, learning, brain based learning

Abstrak: Tulisan ini membahas tentang perkembangan akidah akhlak manusia menggunakan brain based learning. Penulis mengidentifikasikan akan adanya pembelajaran yang statis didalam pendidikan akidah akhlak. Untuk menciptakan pembelajaran akidah akhlak yang lebih menyenangkan dan modern maka dibuatlah metode brain based learning. Di dalamnya berisikan strategi tentang pembelajaran akidah akhlak yang menggunakan metode brain based learning yang juga di padukan dengan pembelajarab yang aktif dan efektif dan sejalan dengan hal itu, demi membentuk manusia yang berakhlak mulia dan berakidah yang kuat untuk mengesakan Allah, maka didalamnya lebih bersikan kepada penanaman pribadi yang baik. Pembelajaran ini mengacu pada pemberdayaan potensi otak agar manusia bisa berfikir secara kritis dan kooperatif dalam menunjang kehidupan berakidah dan berakhlak sesuai dengan pedoman Al-Qur'an dan hadis. Pada pendidikan akidah akhlak dimana perkembangan zaman sudah mencapai era distrubsi ini penerapan metode brain based learning sangat tepat di gunakan sebagai penanggulangan era yang bersifat penghancur itu.

Kata Kunci: Akidah Akhlak, pembelajaran, brain based learning

\section{Pendahuluan}

Permasalahan akidah akhlak pada zaman sekarang sudah sangat kompleks, hal ini ditunjukan dengan banyaknya pergaulan bebas yang menjadikan anak didik menjadi lebih kasar, melaksanakan kegiatan yang menimbulkan dosa seperti seks bebas, dan tidak mendekatkan diri kepada Allah. Maka dari itu, pendidikan akidah akhlak hadir untuk menanggulangi problematika kehidupan masyarakat pada saat ini agar terbentuk kondisi sosial yang kondusif, tentram, agamis dan berperilaku yang bagus. Melalui pendidikan akidah akhlak juga manusia akan bisa menjalani kehidupan damai bersama manusia lain baik satu golongan maupun berbeda golongan, baik satu negara maupun berbeda negara, baik satu agama maupun berbeda dari agama yang kita anut.

Pendidikan akidah akhlak merupakan pendidikan yang bertujuan untuk menambah keyakinan kepada Allah SWT serta meningkatkan perilaku baik sesuai dengan Al-Qur'an dan sunnah melalui jalur pembelajaran. Pembahasan 
tentang akidah akhlak ini penting agar memiliki pengetahuan dan pemahaman yang utuh atas keimanan. ${ }^{1}$ Pendidikan akidah akhlak mampu memberikan dukungan spiritual untuk manusia agar bisa menjadi insan yang baik budi pekertinya baik kepada manusia. Disamping itu, dengan adanya penanaman akidah akhlak akan menjadikan manusia lebih menghargai ciptaan Allah seperti hewan, tumbuhan, dan segala yang ada di dunia ini, dan aspek yang terpenting adalah untuk mendekatkan diri kepada Allah SWT.

Pendidikan akidah akhlak pada zaman sekarang identik dengan pendekatan kepada agama saja yang bersifat statis dan hanya terfokus pada akhirat saja, akan tetapi apabila penanaman pendidikan akidah akhlak di kemas dengan cara menyenangkan dan modern maka akan tercipta pembelajaran akidah akhlak yang sesuai dengan kondisi zaman yang saat ini. Perlu adanya penekanan pendidikan akidah akhlak didalam pendidikan didasarkan pada kinerja guru di Sekolah yang mengedepankan prestasi dibandingakan dengan akhlak. Siswa dipandang baik karena memiliki prestasi dan kecerdasan yang bagus tanpa mempertimbangkan akidah akhlaknya. Oleh karena itu, pendidikan secara terus menerus di bangun dan dikembangkan agar didalam proses pelaksanaanya menghasilkan generasi yang diharapkan. ${ }^{2}$ Pembelajaran akidah akhlak disesuaikan dengan dinamika perkembangan zaman ini sangat cocok menggunakan pembelajaran berbasis kemampuan otak (brain based learning). Eric Jensen memaparkan bahwa brain based learning adalah sistem pembelajaran yang berbasis dengan kemampuan otak adalah pembelajaran yang diselaraskan dengan cara otak yang didesain secara ilmiah untuk belajar. Dalam artian yang lebih singkat lagi adalah pendekatan berbasis kemampuan otak. ${ }^{3}$ Pembelajaran berbasis kemampuan otak ini merupakan sebuah cara berpikir tentang proses pembelajaran. Ketika belahan otak kanan dan otak kiri digunakan, maka kekuatan dan fungsi- fungsi otak manusia maksimal. Bahkan bekerjanyapun menjadi maksimal. Dampak positif yang bisa dirasakan ialah kecerdasan seorang atau seorang anak akan semakin meningkat. Fungsi otak tersebut tidak hanya bekerja sendiri-sendiri tetapi saling mempengaruhi satu sama lain. ${ }^{4}$

\footnotetext{
${ }^{1}$ Nurul Hidayati Rofiah, Desain Pengembangan Pembelajaran Akidab Akblak Di Perguruan Tinggi, Fenomena Hal 56

2 Akhmad Muhaimin Azzet. 2011 Urgensi Pendidikan Karakter di Indonesia Yogjakarta: Ar-Ruzz Media

${ }^{3}$ Jensen, Eric. 2008 Brain Based Learning, Yogyakarta: pustaka pelajar

${ }^{4}$ Masykur, Moch dan Abdul Halim Fathani. (2008). Mathematical Intelligence : Cara Cerdas Melatih Otak dan Menanggulangi Kesulitan Belajar. Jogjakarta. Ar-Ruzz Media
} 


\section{Pendekatan Pendidikan Akidah Akhlak}

Sebelum masuk kedalam inti pembahasan brain based learning, perlu diketahui bahwa akidah akhlak mempunyai sistem pendekatan yang digunakan untuk menentukan kualitas proses pendidikan akidah akhlak. Salah satu pendekatan yang dapat digunakan untuk menentukan kualitas proses pembelajaran adalah pendekatan sistem. Melalui pendekatan sistem kita dapat melihat berbagai aspek yang dapat mempengaruhi keberhasilan suatu proses. Pendekatan sistem mengandung dua aspek, yakni aspek filosofis dan aspek proses. Aspek filosofis adalah pandangan hidup yang mendasari sikap perancang sistem yang terarah pada kenyataan. Sedangkan aspek proses adalah suatu perangkat alat konseptual. Gagasan inti sistem filosofis ialah bahwa suatu sistem merupakan sekumpulan dari sejumlah komponen yang saling berinteraksi dan saling bergantungan satu sama lain. Pendekatan sistem merupakan tujuan secara operasional, mengembangkan deskripsi tugas secara lengkap dan akurat, dan melaksanakan analisis tugas. Ada dua ciri pendekatan sistem pembelajaran, yaitu:

\section{Pendekatan sistem}

Merupakan pendekatan tertentu yang mengarah ke proses belajar mengajar. Proses belajar mengajar adalah suatu penataan yang memungkinkan guru dan siswa berinteraksi satu sama lain untuk memberi kemudahan bagi siswa belajar.

\section{Penggunaan metodologi}

Metodologi khusus untuk mendesain sistem pembelajaran. Metodologi itu terdiri atas prosedur sistemik perencanaan, perancangan, pelaksanaan, dan penilaian keseluruhan proses belajar mengajar. Kegiatan tersebut diarahkan untuk mencapai tujuan khusus dan didasarkan pada penelitian dalam belajar dan komunikasi. Penerapan metodologi tersebut akan menghasilkan suatu sistem belajar yang memanfaatkan sumber manusiawi dan non manusiawi secara efisien dan efektif. Dengan demikian, pendekatan sistem merupakan suatu panduan dalam rangka perencanaan dan penyelenggaraan pengajaran. ${ }^{5}$

Dari dua ciri pendekatan sistem pembelajaran kita dapat memberikan kesimpulan bahwa pendekatan dari sistem akidah akhlak yang mengarah kepada proses pembelajaran terstruktur yang dilakukan agar mempermudah

\footnotetext{
${ }^{5}$ Nurul Hidayati Rofiah, Desain pengembangan Pembelajaran Akidah Akblak Di Perguruan Tinggi, Fenomena hal 59-60
} 
pembelajaran akidah akhlak tersebut. pembelajaran yang mudah akan menjadikan anak merasa mudah pula dalam belajar sehingga mereka tidak merasa tertekan dengan apa yang gurunya ajarkan. Disamping itu pembelajaran yang mudah pula akan meningkatkan motivasi agar peserta didik ingin belajar dan bersungguh-sungguh khususnya dalam peningkatan akidah dan akhlak mereka.

\section{Korelasi Antara Brain Based Learning Dengan Otak Peserta Didik}

Brain based learning dalam pembelajaran menawarkan sebuah konsep untuk menciptakan pembelajaran dengan berorientasi pada upaya pemberdayaan otak siswa. ${ }^{6}$ Upaya pembelajaran ini mempertimbangkan dari kemampuan otak siswa dalam memperoleh ilmu pengetahuan yang tidak hanya berasal dari guru saja, melainkan dari pemikiran peserta didik sendiri. Brain based learning erat kaitannya dengan otak. Otak yang dipakai dalam pembelajaran brain based learning yaitu otak rasional (IQ), otak emosional(EQ), dan otak spiritual (SQ).

1. Otak rasional merupakan otak yang berpusat pada bagian luar otak besar yang berwarna abu-abu. ${ }^{7}$ Sistem kerja otak ini bertumpu pada kemampuan rasional (IQ) anak didik untuk bisa memahami suatu pembelajaran maupun permasalahan berdasarkan apa yang mereka anggap baik sesuai dengan rasional mereka. Peran kerja dari otak ini sangat diperlukan karena pada dasarnya pendidikan akidah akhlak adalah menjadikan manusia yang yang beriman dan mengesakan Allah dalam setiap tindakannya serta berbudi dan berakhlak yang baik terhadap orang lain juga semua makhluk yang berada di sekitarnya. Hal ini selaras dengan akal rasional manusia yang cenderung melaksanakan kebaikan dan meninggalkan keburukan.

Otak rasional tidak akan berfungsi apabila tanpa adanya peran dari otak emosional dan otak spiritual.Oleh karena itu pendekatan otak secara keseluruhan (whole brain approach) akan secara jelas memperlihatkan tidak dapat di pisahkannya masalah kognisi dengan emosi sebagai satu kesatuan. Rasionalitas dalam pembelajaran harus melibatkan emosionalitas dengan cara

\footnotetext{
${ }^{6}$ Wayan Widiana, Gede Wira Bayu, Nyoman Laba, Ayata. Pembelajaran Berbasis Otak (Brain Based Learning), Gaya Kognitif Kemampuan Berpikir Kreatif Dan Hasil Belajar Mahasiswa. Jurnal Pendidikan Indonesia. Hal: 3

7 Suyadi. 2017. Teori Pembelajaran Anak Usia Dini Dalam Kajian Neurosains. Bandung: PT Rosdakarya hal: 177
} 
mengemas materi pelajaran dalam bentuk gambar, kata, dan suara. Berdoa sebelum belajar adalah gerbang memasuki dimensi emosi-spiritual. ${ }^{8}$

Dalam pembelajaran diruang kelas ataupun ruang baca yang kaya dengan stimulasi akan membantu kinerja otak secara keseluruhan sepanjang proses pembelajaran. Pemanfaatan memahami emosi dari peserta didik merupakan kunci untuk membangun motivasi belajar mereka. Jika informasi hanya dikemas dalam bentuk kata-kata atau teks bacaan, ia hanya disimpan dalam otak kiri (memori jangka pendek), sedangkan ketika informasi dikemas juga dalam bentuk gambar yang penuh warna ia akan disimpan dalam memori jangka panjang. Oleh karena itu, materi pelajaran harus dikemas dalam bentuk kata-kata, teks, gambar, dan suara.

2. Otak emosional (EQ) merupakan otak yang berpusat pada sistem limbik. ${ }^{9}$ Sesuai dengan namanya yaitu otak emosional, otak ini adalah otak yang menunjukan bahwa perkembangan didalam diri manusia diawali dari perkembangan emosional. Perkembangan pemikiran peserta didik bahkan cenderung untuk berpikir melalui fungsi otak emosional dahulu dibandingkan dengan otak rasional. Oleh karena itu anak didik cenderung bertingkah emosi apabila ada yang bertentangan dengan pemikirannya dan setelah itu baru mereka memikirkan hal yang bertentangan tadi dengan otak rasional.

Perlu diketahui juga bahwa otak emosional itu bukan hanya dengan hal yang berhubungan dengan emosi ataupun hal yang menyebalkan, akan tetapi bisa memberikan rasa gembira, semangat, antusias ${ }^{10}$ juga merupakan bagian dari otak emosional. Namun otak rasional tidak dapat bekerja sendirian tanpa peran dari otak rasional dan otak spiritual. Antonio Damasio mennyatakan bahwa emosi dan rasio, termasuk spiritual terangkai menjadi satu kesatuan dalam jaringan neural dari akal sehat. ${ }^{11}$ Akan tetapi Damasio juga menyatakan bahwa emosi yang tidak terkendali atau tidak terarahkan dapat menjadi sumber utama dari perilaku yang irrasional (bertentangan denga perilaku rasional), akan tetapi mengurangi emosi juga menjadi sumber yang sama pentingnya dalam membentuk perilaku irrasional. Hasil yang terjadi dari pembentukan emosional yang ada didalam peserta didik disebut dengan kecerdasan emosional.

\footnotetext{
${ }^{8}$ Ibid hal: 118

${ }^{9}$ Ibid hal: 119

${ }^{10}$ Ibid hal 120

${ }^{11}$ Jensen, Eric. 2008 Brain Based Learning, Yogyakarta: pustaka pelajar
} 
Didalam pembentukan emosional perlu juga pengendalian emosi, emosi yang berlebih apabila tidak di kendalikan secara benar maka akan terjadi penyaluran emosi yang negatif, akan tetapi apabila sudah tejadi pengendalian emosi yang baik maka pengeluaran dari emosi tersebut juga akan ikut positif

3. Otak spiritual(SQ) berpusat pada ketuhanan yang berada di lobus temporal. Bagian inilah basis neurologis dibangnya kesadaran tingkat tinggi (spiritualitas) manusia. Kesadaran tersebut dibangun oleh adanya sel-sel kelabu dalam otak. Jika sel-sel ini bekerja, lahirlah pikiran rasional yang merupakan titik pijak awal menuju kesadaran tingkat tinggi (spiritual) tersebut. ${ }^{12}$ secara neurologis, tuhan telah meninggalkan jejak dalam diri manusia. Adanya titik ketuhanan membuat manusia sanggup berpikir dalam kerangka nilai. Pelembagaan nilai tersebut secara umum disebut agama dan merupakan sistematisasi dari fungsi spiritual otak. Jadi, ketika seorang menganut suatu agama, ia berarti sedang mewujudkan dimensi spiritual atas otaknya. Demikian halnya ketika seseorang tidak menganut agama secara formal, tetapi mewujudkan dimensi spiritual dalam otaknya. Dengan demikian, optimalisasi otak spiritual akan membuat seseorang hidup lebih baik dan bermakna apapun agamanya. ${ }^{13}$ Otak spiritual, tempat terjadinya kontak manusia dengan tuhan melalui alam pikiran hanya akan berperan jika otak rasional dan panca indra telah difungsikan secara optimal.

Dengan demikian, seorang pencari ilmu tidak akan mendapatkan hidayah dari Allah jika ia tidak memaksimalkan fungsi otak rasional dan panca indranya. Kesadaran diri merupakan fungsi internal dari otak manusia. Tanpa rangsangan dari luar sekalipun, kesadaran diri tetap ada. Dalam konteks ini, sistem pendidikan harus membuka kesempatan yang lebar bagi pemenuhan rasa rindu untuk menemukan nilai dan makna dari apa yang diperbuat dan dialami sehingga anak didik dapat memandang kehidupan dalam konteks yang bermakna.

Cara kerja otak spiritual tersebut berpikir intuitif. Hasil kerja dari kecerdasan intuitif tersebut yang dinamakan kecerdasan spiritual. Pada dasarnya SQ merupakan kecerdasan untuk menghadapi dan memecahkan persoalan, khususnya terkait dengan makna hidup dan nilai. SQ yang kuat akan menjadi landasan kokoh untuk memfungsikan IQ dan EQ secara efektif. SQ digunakan

\footnotetext{
${ }^{12}$ Kushartanti, BM Wara. 2003. Perkembangan aplikasi neurosains dalam pembelajaran di TK. Yogyakarta: Klinik terapi fisik FIK UNY.

${ }^{13}$ Ibid hal: 16
} 
untuk bergulat dengan hal-hal yang ikhwah baik dan buruk, serta untuk membayangkan kemungkinan yang belum terwujud.

Salah satu cara untuk mengoptimalkan otak spiritual adalah dengan melihat permasalahan secara utuh, mengkaji yang tersirat dari yang tersurat, dan merenungkannyasecara mendalam. Berdoa dengan berbagai cara di setiap agama merupakan sarana ampuh untuk mengoptimalkan otak spiritual. Cara ini akan mendukung pemecahan masalah dengan otak emosional, intuitif, juga spiritual. ${ }^{14}$

\section{Kualitas Pendidikan Akidah Akhlak Menggunakan Brain Based Learning}

Brain based learning merupakan sebuah konsep untuk menciptakan pelajaran dengan berorientasi pada upaya pemberdayaan potensi otak. ${ }^{15} \mathrm{Otak}$ berperan besar dalam pengembangan brain based learning dikarenakan metode brain based learning merupakan metode yang berpusat pada otak untuk membentuk daya intelektualitas yang tinggi didalam pembelajaran akidah akhlak. Jika pembelajaran sejenis ini di gali lebih dalam maka akan mempermudah pembelajaran akidah akhlak.

Pendidikan generasi sekarang tidak bisa dididik hanya dengan bermodalkan pembelajaran dan anak mendengarkan. Ali ibn Abi Thalib pernah berkata, "janganlah engkau didik anakmu sebagaimana engkau dulu memperoleh pendidikan karena mereka dilahirkan di zaman yang berbeda dengan zamanmu"16. Sebagian guru konvensional menyadari akan perbedaan murid zaman sekarang dengan zaman dulu, anak zaman sekarang lebih cenderung untuk mendapatkan suatu ilmu yang instan, anak zaman sekarang juga cenderung melakukan suatu hal yang bersifat hiburan atau yang bersifat mengasyikan, hal ini di karenakan pesatnya ilmu pengetahuan sehingga anak didik bisa dengan leluasa mencari informasi baik itu bermanfaat ataupun merugikan. Maka dari itu, perlu adanya pembaharuan pendidikan, khususnya pendidikan akidah akhlak agar anak mampu memperkokoh sendi keislamannya. Dalam strategi pendidikan akidah akhlak, brain based learning mencangkup pendidikan yang berkarakter.

\footnotetext{
${ }^{14}$ Suyadi. 2017. Teori Pembelajaran Anak Usia Dini Dalam Kajian Neurosains. Bandung: PT Rosdakarya

15 Chamidiyah, Pembelajaran Melalui Brain Based Learning Dalam Pendidikan Anak, edukasia hal 287

16 Suyadi. 2017. Teori Pembelajaran Anak Usia Dini Dalam Kajian Neurosains. Bandung: PT Rosdakarya
} 
Dalam pusat bahasa Depdiknas menjelaskan karakter adalah bawaan, hati, jiwa, kepribadian, budi pekerti, perilaku, personalitas, bersifat, bertabiat, dan berwatak. ${ }^{17}$ Menurut Suyadi pendidikan karakter yang sekarang di dengung dengungkan oleh Kemendiknas sebenarnya hanya istilah lain dari pendidikan budi pekerti dalam pemikiran Ki Hadjar Dewantara. ${ }^{18}$ Ahmad Amin mengemukakan bahwa kehendak (niat) merupakan awal terjadinya akhlak (karakter) pada diri seseorang jika kehendak itu di wujudkan dalam bentuk pembiasaan sikap dan perilaku.

Di dalam akidah akhlak ini brain based learning akan menjadi sarana untuk mengembangkan karakter manusia yang baik sesuai dengan pengetahuan yang dimiliki oleh orang tersebut dan di dukung dengan daya intelektual yang tinggi dari brain based learning tersebut. Pengembangan ini akan menjadikan kualitas dari pendidikan akidah akhlak menjadi baik secara signifikan dan berkemajuan sesuai dengan peradaban modern di dunia ini.

\section{Penerapan Akidah Akhlak Menggunakan Metode Brain Based Learning}

Setidaknya ada beberapa metode yang bisa di tawarkan untuk mengembangkan pendidikan akidah akhlak melalui brain based learning. Metode-metode tersebut yaiu:

1. Penyampaian guru didalam pembelajaran akidah akhlak dengan cara yang kreatif seperti mengajarkan keimanan kepada Allah melalui pennghafalan setiap sifat Allah menggunakan kode gerakan anggota tubuh tertentu. Kode gerakan tertentu itu di berikan seperti ini: menghafal rukun iman ataupun rukun islam menggunakan gerakan, rukun iman yang pertama yaitu beriman kepada Allah penghafalanya menggunakan jari telunjuk yang diarahkan ke atas sebagai metode penghafalannya, begitupun selanjutnya. Setiap rukun iman yang kita hafalkan maka bentuk dari visualisasi gerakanya ikut berbeda pula.

2. Melalui proses menggambar. Pendidikan akidah akhlak melalui metode gambar ini bisa di terapkan untuk anak-anak untuk jenjang pendidikan TK$\mathrm{SD}$, metode ini realisasinya yaitu peserta didik diberikan satu soal bisa mengenai akidah akhlak. Sebagai contoh, rukun Islam yang kedua adalah? Lalu anak didik di minta untuk menggambarkan rukun Islam yang kedua

\footnotetext{
17 Yulvinamaesari. Implementasi Brain Based Learning Dalam Pembelajaran Berbasis Pendidikan Karakter. Prosdiring seminar nasional hal 102

${ }^{18}$ Suyadi.2015. Strategi Pembelajaran Pendidikan Karakter. Bandung: Rosdakarya
} 
tersebut. Maka otomatis anak didik akan menggambar orang yang sedang shalat. Dengan melalui visualisasi gambar anak didik akan lebih tertarik untuk belajar akidah akhlak dan meningkatkan daya kreativitas anak tersebut.

3. Pembelajaran akidah akhlak melalui visualisasi gambar. Sekilas pembelajaran berbentuk visualisasi gambar hampir mirip dengan menggunakan metode proses menggambar, akan tetapi berkebalikan dengan metode tersebut. Metode ini menggunakan gambar sebagai aktualisasi dari pendidikan akidah akhlak. metode melalui visualisasi gambar ini lebih ke bagaimana anak memahami gambar untuk mengenal akidah akhlak. sebagai contoh: diberikan gambar orang yang sedang makan sambil berdiri, anak diminta untuk mengidentifikasi perilaku atau akhlak orang yang berada di gambar tersebut. Karena tidak baik dan tidak sesuai dengan akhlak yang baik maka peserta didik diharapkan bisa menerapkan sikap yang baik karena telah mengidentifikasi adanya kejanggalan di dalam gambar tersebut. penggunaan metode ini juga bertujuan agar peserta didik memiliki daya peka terhadap kondisi di lingkungan agar mereka juga bisa mencipkatakan kondisi yang baik di lingkungan bermain, maupun lingkungan keluarga mereka. Disamping itu, juga diharapkan agar murid memiliki kemampuan untuk memahami diri sendiri ${ }^{19}$ melalui metode visualisasi gambar tersebut.

4. Pembelajaran akidah akhlak melalui video. Peserta didik diperlihatkan video berkaitan dengan akidah akhlak. bisa berupa sesuatu yang baik dan juga bisa berupa sesuatu yang buruk. Dengan menonton video tersebut anak akan lebih memahami, disamping itu, pemberian materi pembelajaran menggunakan video ini sangat ampuh, karena anak didik lebih bisa memahami, disamping itu guru juga perlu memberikan penjelasan secara jelas agar murid tidak salah mengartikan apa maksud dengan diperlihatkan video tentang akidah akhak tersebut.

5. pembelajaran akidah akhlak melalui media komunikasi, dimana di dalam prosesnya guru lebih banyak menunjukan akidah dan akhlak yang baik. Penunjukan dari guru ini lebih efektif karena guru di dalam Sekolah itu adalah seseorang yang dijadikan teladan bagi anak didik dan mereka cenderung mengikuti apa yang guru ajarkan kepadanya.

Pelaksanaan pembelajaran akidah akhlak ini akan memberikan kemudahan bagi pendidik untuk menyampaikan kepada anak didik, pelaksanaan ini pula akan membuat anak didik lebih bisa berpikir lebih kritis sejalan dengan

${ }^{19}$ Suyadi. 2017. Teori Pembelajaran Anak Usia Dini Dalam Kajian Neurosains. Bandung: PT Rosdakarya 
pendidikan akidah akhlak. pembelajaran akidah akhlak ini bisa menimbulkan perkembangan kognitif anak untuk mengeksprorasi kemampuan berpikir peserta didik.

\section{Kelebihan Dan Kekurangan Pendidikan Akidah Menggunakan Metode Brain Based Learning}

Di dalam suatu proses pendidikan tidak bisa menafikkan bahwa dibalik kelebihan suatu metode akan ada juga kekurangan dari metode yang ditawarkan. Kelebihan dan kekurangan tersebut bisa menjadikan positif dan bisa menjadi negatif tergantung siapa yang bisa memanfaatkannya. Berikut kelebihan dan kekurangan penggunaan metode brain based learning di dalam pendidikan akidah akhlak:

Kelebihan pendidikan akidah akhlak menggunakan metode brain based learning antara lain adalah:

1. Menciptakan iklim pelajaran yang menyenangkan dan mendukung untuk pendidikan akidah akhlak.

2. Di dalam pembelajaran akidah akhlah menggunakan brain based learning akan tercipta pembelajaran yang menyenangkan karena ciri khas dari pembelajaran brain based learning sendiri adalah pembelajaran yang menyenangkan.

3. Dapat menggunakan berbagai model pembelajaran di dalam proses belajar mengajar.

4. Pembelajaran akidah akhlak menggunakan brain based learning bisa menggunakan berbagai model pembelajaran karena otak akan bekerja lebih baik apabila melaksanakan hal yang demikian.

5. Memerhatikan kerja alamiah otak siswa yang belajar menggunakan brain based learning dalam proses pembelajaran.

6. Brain based learning memperhatikan kinerja peserta didik menggunakan pemikiran yang bisa dikembangkan didalam otak peserta didik

7. Pembelajaran mengenai akidah akhlak akan lebih bersifat modern dan baru

8. Pembelajaran ini tergolong pembelajaran yang baru karena masih sedikit institusi yang mengamalkan pembelajaran menggunakan brain based learning tersebut 
9. Bisa mengambil keputusan yang baik tanpa harus melihat hukum yang ada karena didalam pemikirannya sudah melekat pendidikan akidah akhlak yang baik. $^{20}$

Kelemahan pendidikan akidah akhlak menggunakan metode brain based learning antara lain adalah;

1. Tenaga kependidikan di indonesia belum sepenuhnya mengetahui teori pengetahuan brain based learning.

2. Perlu adanya pensosialisasian agar pendidik memahami brain based learning dan dapat mengamalkannya kepada peserta didik.

3. Memerlukan waktu lama untuk memahami bagaimana otak bekerja didalam pelajaran.

4. Pemahaman ini akan bisa lebih cepat apabila sudah terbiasa dengan suasana pembelajaran menggunakan brain based learning

5. Memerlukan modal untuk menciptakan model pembelajaran yang baik bagi otak. $^{21}$

\section{Penutup}

Pendidikan akidah akhlak menggunakan metode brain based learning ini merupakan metode baru didalam pendidikan berbasis agama. Didalamnya terdapat berbagai cara yang bisa di pelajari oleh pendidik agar mereka bisa mengajarkan pendidikan akidah akhak kepada peserta didik dengan cara yang menyenangkan. Didalam metode brain based learning anak didik diharuskan lebih aktif untuk memikirkan ataupun menyelesaikan permasalahan yang ada didalam akidah akhlak ataupun memberikan pendapat agar akidah dan akhlak mereka senantiasa berpegang teguh terhadap tali Al-Qur'an dan hadist yang diberikan kepada Nabi Muhammad SAW.

Cara-cara yang diberikan didalam pendidikan akidah akhlak menggunakan metode brain based learning antara lain seperti metode menghafal, menggunakan gambar-gambar, visualisasi dari video dan masih banyak lagi yang bisa di berikan menggunakan brain based learning. Hal tersebut memberikan pemahaman yang jelas bagi peserta didik. Model pembelajaran ini terbukti menarik untuk meningkatkan penguasaan ilmu

\footnotetext{
${ }^{20}$ Ibid hal 169

${ }^{21}$ Lailatul Hidayah. Efektivitas Model Pembelajaran Brain Based Learning (BBL) Dengan Pendekatan Saintifik Berbantu Alat Peraga Sederhana Terbadap Hasil Belajar Matematika Peserta Didik Kelas VIII Pada Materi Garis Singgung Lingkaran. Skripsi UIN W alisongo. Hal 12
} 
pengetahuan disamping memastikan perkembangan potensi menyeluruh di kalangan peserta didik. Melalui pembelajaran yang demikian, maka peserta didik akan termotivasi mengikuti pembelajaran, memiliki pemahaman konsep mendalam, dan pengembangan potensi peserta didik yang signifikan. Terlepas dari kelebihan dan kekurangan yang ada pada metode ini, brain based learning bisa menjadi salah satu cara untuk memajukan pendidikan yang sekarang ini hanya lebih terpaku kepada nilai, tidak dengan skill yang dimiliki oleh peserta didik sendiri. Dengan metode brain based learning peserta didik dapat lebih mengeskplor dirinya agar bisa berpikir secara mendalam mengenai persoalan akidah akhlak yang belum terselesaikan sampai sekarang.

\section{Bibliografi}

Akhmad Muhaimin Azzet. 2011 Urgensi Pendidikan Karakter di Indonesia Yogjakarta: Ar-Ruzz Media

Chamidiyah, Pembelajaran Melalui Brain Based Learning Dalam Pendidikan Anak usia dini, edukasia

Jensen, Eric. 2008 Brain Based Learning, Yogyakarta: pustaka pelajar.

Kushartanti, BM Wara. 2003. Perkembangan aplikasi neurosains dalam pembelajaran di TK. Yogyakarta: Klinik terapi fisik FIK UNY.

Lailatul Hidayah. Efektivitas Model Pembelajaran Brain Based Learning (BBL) Dengan Pendekatan Saintifik Berbantu Alat Peraga Sederbana Terbadap Hasil Belajar Matematika Peserta Didik Kelas VIII Pada Materi Garis Singgung Lingkaran. Skripsi UIN Walisongo. Hal 12

Nurul Hidayati Rofiah, Desain Pengembangan Pembelajaran Akidah Akblak Di Perguruan Tinggi, Fenomena

Suyadi. 2017. Teori Pembelajaran Anak Usia Dini Dalam Kajian Neurosains. Bandung: PT Rosdakarya

Suyadi.2015. Strategi Pembelajaran Pendidikan Karakter. Bandung: Rosdakarya

Taufiq Paisak. 2012. Tuhan Dalam Otak. Manusia, Mewnijudkan Kesehatan Spiritual Berdasarkan Neurosains. Bandung. Mizan.

Yulvinamaesari. Implementasi Brain Based Learning Dalam Pembelajaran Berbasis Pendidikan Karakter. Prosdiring seminar nasional. 
74 | Belajea : Jurnal Pendidikan Islam, Vol. 4, No. 01, 2019 